Implikasi Pendidikan Islam dalam Keluarga... | 53

\title{
IMPLIKASI PENDIDIKAN ISLAM DALAM KELUARGA DAN KEPRIBADIAN ANAK
}

\author{
Ahmad Masduki 1) * \\ ${ }^{1}$ GPAI SMK YPE Nusantara Slawi \\ *E-mail: Ahmad.masduki69@gmail.com
}

\begin{abstract}
This research is motivated by the importance of Islamic education in the family. How can family life be integrated with the practice of religious teachings. Family and religion are two inseparable provisions, from building a family to life in a family. So to what extent is the role of religious education in family life.The method in this writing is library research or library research with documentation study techniques. The point is to describe the background of the problem, the author collects data from books, journals, scientific papers, and so on. Then analyzed with a reflective thinking approach, which is a combination of induction and deduction approaches. The description of the results of the analysis shows that the family has a very big influence on children's development for the future. It is the family that gives color to a child's life, in terms of behavior, character, religious practice and daily customs. The family is also where a child gets hammered first which then determines the good and bad of life afterward in society. The application of religious education to children in the family greatly influences the formation of attitudes and behavior and personality of children. The provision of religious assets in the family implies that children have knowledge of the basics of religion, morals and social. These basic knowledge have important meaning for the achievement of the basic goals of Islamic education, namely the cultivation of faith and morals.
\end{abstract}

Keywords: Islamic Education, Family, Personality

\begin{abstract}
Abstrak
Penelitian ini dilatarbelakanginya oleh pentingnya pendidikan Islam dalam keluarga. Bagaimana kehidupan berkeluarga bisa berintegrasi dengan amaliah ajaran agama. Keluarga dan agama adalah dua ketentuan yang tidak bisa dipisahkan, sejak akan membangun keluarga sampai kehidupan dalam berkeluarga. Maka sejauh mana peranan pendidikan agama dalam kehidupan keluarga. Metode dalam penulisan ini adalah dengan penelitian kepustakaan atau library research dengan teknik studi dokumentasi. Maksudnya adalah mendeskripsikan latar belakang dari permaslahan , penulis mengumpulkan data dari buku-buku, jurnal, karya ilmiah, dan lain sebagainya. Kemudian dianalisis dengan pendekatan reflektif thinking, yaitu kombinasi antara pendekatan induksi dan deduksi. Deskripsi dari hasil analisisnya menunjukkan bahwa keluarga memberikan pengaruh yang sangat besar bagi perkembangan anak untuk masa yang akan datang. Keluargalah yang memberikan warna kehidupan seorang anak, baik perilaku, budi pekerti, amaliah beragama maupun adat kebiasaan sehari-hari. Keluarga jugalah tempat seorang anak mendapat tempaan pertama kali yang kemudian menentukan baik buruk kehidupan setelahnya di masyarakat. Penerapan pendidikan agama terhadap anak dalam keluarga sangat berpengaruh terhadap pembentukan sikap dan tingkah laku serta kepribadian anak. Pemberian modal-modal keagamaan dalam keluarga berimplikasi pada anak untuk memiliki pengetahuan dasar-dasar keagamaan, akhlak dan sosial. Pengetahuan-pengetahuan dasar tersebut memiliki arti penting untuk pencapaian tujuan asasi dari pendidikan Islam, yaitu penanaman iman dan akhlakul karimah.
\end{abstract}

Kata Kunci: Pendidikan Islam, Keluarga, Kepribadian

Vol. 3, No. 2, Agustus 2020 


\section{PENDAHULUAN}

Komponen terkecil dari kelompok sosial adalah keluarga yang terdiri dari ayah, ibu dan anak. Pergaulan yang dilakukan dalam keluarga akan memberikan pengaruh yang sangat besar bagi perkembangan anak untuk masa yang akan datang, karena keluargalah yang memberikan warna kehidupan seorang anak, baik perilaku, budi pekerti, ibadahnya, dan dalam membaca Al-Quran maupun adat kebiasaan sehari-hari. Keluarga juga merupakan tempat seorang anak mendapat tempaan pertama kali yang kemudian menentukan baik buruk kehidupan setelahnya di masyarakat. Sehingga tidak salah lagi kalau keluarga adalah elemen penting dalam menentukan baikburuknya masyarakat.

Keluarga diibaratkan sebagai negara kecil yang dijadikan sebagai lambang bagi kesatuan yang ideal dengan unsur persatuan, ketentraman, kebaikan, kebahagiaan serta kedamaian yang dirasakan oleh segenap anggotanya, namun kejadian ini bukan berarti tidak mungkin terjadi gangguan atau penyimpangan fungsi dalam struktur keluarga. Misalnya kesulitan berupa keuangan, ketidak harmonisan, perceraian, kejahatan, penyelewengan dan sebagainya yang merupakan ancaman bahaya dan menimbulkan krisis di tengah struktur keluarga. Oleh karena itu kehidupan keluarga di tengah-tengah masyarakat luas perlu adanya kekatan fisik maupun psikis.

Pendidikan dan pembinaan yang diterima anak pertama kali adalah melalui keluarga. Meskipun diakui bahwa sekolah mengkhususkan diri untuk kegiatan pendidikan, namun sekolah tidak mulai dari ruang hampa, artinya sekolah menerima anak setelah melalui berbagai pengalaman dan sikap serta memperoleh banyak pola tingkah laku dan keterampilan yang diperolehnya dari lembaga keluarga.

Perkembangan ilmu pengetahuan dan teknologi yang saat kini merupakan era industri dan era digital yang era tersebut tidak hanya mendatangkan kebahagiaan dan kemudahan, tetapi juga menimbulkan masalah etis dan kejiwaan baru bagi manusia. Efek tersebut ternyata berdampak pada sosiologis, psikologis dan bahkan teologis. Bahkan perubahan yang terjadi juga mempengaruhi nilai-nilai budaya dan norma yang baik yang selama ini dianut dan dilakukan oleh masyarakat, sehingga terjadi krisis nilai (Muflihin, 2016). Realita yang demikian yang terjadi di masyarakat akan sangat jelas berpengaruh pada kehidupan keluarga, karena antar keluarga terjadi komunikasi antar keluarga dalam kehidupannya. 
Dalam mensikapi fenomena tersebut, maka berangkat dari orang tua yang merupakan pendidik dalam keluarga harus selalu berpijak pada aturan agama Islam dalam kehidupannya sehingga akan mudah dalam penanaman nilai-nilai atau ajaran agama Islam pada anaknya untuk diamalkan sehingga akan terwujud kualitas keluarga yang berlandaskan keimanan dan berakhlajul karimah dalam perilakunya. Harus disadari bahwa keluarga merupakan titik awal keberangkatan sekaligus sebagai modal awal perjalanan hidup mereka.

Berdasarkan uraian di atas, maka tujuan dari penulisan ini adalah untuk medeskripsikan tentang peran utamanya pendidikan Islam dalam kehidupan keluarga pada siswa SMK YPE Nusantara Slawi yang mengikuti ekstrakurikuler kerohanian Islam yang adanya interaktif antara ayah, ibu dan anak dalam ikatan yang kuat untuk terwujudnya kehidupan keluarga yang bahagia, tenteram, damai dan melaksanakan ajaran agama Islam serta bisa memberikan dampak positif bagi lingkungannya.

\section{METODE}

Dilihat dari sumber data, penelitian yang digunakan dalam penulisan ini adalah penelitian kepustakaan atau library research dengan teknik studi dokumentasi dan interaktif. Maksudnya adalah untuk mendeskripsikan latar belakang tersebut, penulis mengumpulkan data dari buku-buku, jurnal, karya ilmiah, dan lain sebagainya kemudian melihat kesesuaian yang ada pada siswa yang mengikuti ekstra rohis di SMK YPE Nusantara Slawi. Hal ini sejalan dengan pendapat Mestika Zed yang menjelaskan bahwa penelitian kepustakaan atau library research adalah penelitian yang kajiannya dilaksanakan dengan menelaah dan menelusuri berbagai literatur, buku atau karya ilmiah (Zed, 2008:3). Kemudian dianalisis dengan pendekatan reflektif thinking, yaitu kombinasi antara pendekatan induksi dan deduksi. Dengan mereduksi data kualitatif dan hasil interaktif dengan siswa rohis, maka penulis dapat memastikan kebenaran pada literature yang menjadi dasar pembahasan.

\section{HASIL DAN PEMBAHASAN}

Paparan hasil kajian pustaka dengan mengamati kepribadian anak yang diikuti dengan penggalian informasi tentang kondisi keluarganya di rumah bagi siswa SMK YPE Nusantara Slawi sebagai bahan control terhadap teori yang dikaji, maka ada tiga 
pembahasan dalam hal ini yaitu tipe keluarga, peran pendidikan Islam dalam keluarga, dan peran keluarga bagi anak.

\section{Tipe Keluarga}

Secara etimologis keluarga berasal dari rangkaian kata "kawula" dan "warga". kawula artinya abdi yakni hamba, sedangkan warga artinya anggota. Sebagai abdi didalam keluarga (Achidsti, 2014), Jadi makna dari arti tersebut adalah seorang wajib menyerahkan segala kepentingannya kepada keluarganya dan warga atau anggota. Sedangkan secara hakiki keluarga mempuyai arti satu persekutuan hidup yang dijalin kasih sayang antara pasangan dua jenis manusia yang dikukuhkan dengan pernikahan, yang bermaksud untuk saling menyempurnakan diri (Dewi, 2012).

Terbentuknya keluarga berawal dari sebuah perkawinan dan keluarga merupakan sarana dalam pembangunan bangsa. Oleh karenanya, manakala sarana atau material bangunannya berkualitas baik maka bangunannya akan kokoh dan kuat, Namun jika material bangunannya berkualitas rendah, maka bangunan itu niscaya akan mudah runtuh pula, dan sesungguhnya satu bangsa itu terdiri dari kumpulan beberapa keluarga ini, lebih lanjut dikatakan bahwa soal perkawinan perlu menjadi perhatian keluarga, yang merupakan jalinan dari hasil perkawinan (Syaltut, 1968 : 141).

Peran Ibu dan bapak dalam keluarga sangat menentukan kefitrahan anak, tidak ada seorang anak yang di lahirkan kecuali dalam keadaan fitrah, maka ibu bapak yang menjadikan yahudi,nasrani atau yang lainya. Anak yang di lahirkan dari keluarga muslim akan condong menjadi muslim, demikian juga anak yang di lahirkan dari keluarga non muslim akan condong kepada agama yang di anut oleh orang tuanya pula. Dari sini fitrah anak harus di jaga agar tetap terpelihara dengan baik.

Pola asuh orang tua dalam proses pendidikan terhadap anaknya sangat dipengaruhi oleh keharmonisan rumah tangga, karena anak akan selalu memperhatikan bagaimana hubungan komunikasi antara ayah dengan ibunya. Anak menilai perilaku yang baik dari kedua orang tuanya yang dijadikan sebagai keteladanan bagi anak dan akan menyerap dan melakukan pada hal yang sama. Dengan demikian orang tua sudah seharusnya bersikap dan berperilaku yang baik sebagai bentuk keteladanan terhadap anaknya sehingga terjalin keharmonisan dalam keluarga. 
Keharmonisan keluarga merupakan bentuk dan harapan yang ingin terus terpelihara dalam keluarga, karena keluarga harmonis merupakan tempat yang menyenangkan dan positif untuk hidup, karena anggotanya telah belajar beberapa cara untuk saling memperlakukan dengan baik. Dikatakan juga bahwa keluarga harmonis adalah keluarga dimana setiap anggotanya menjalankan hak dan kewajibannya masing-masing, terjalin kasih sayang, saling pengertian, komunikasi dan kerjasama yang baik antara anggota keluarga. Sehingga di dalam keharmonisan keluarga harus terwujud saling dukungan, kasih sayang dan menghargai dan menerima perbedaan.

David, mengkategorikan keluarga dalam lima tipe keluarga, yaitu: Keluarga seimbang, yaitu keluarga yang ditandai oleh keharmonisan hubungan (relasi) antara ayah dengan ibu, ayah dengan anak, serta ibu dengan anak. Dalam keluarga ini orang tua bertanggung jawab dan dapat dipercaya. Setiap anggota keluarga saling menghormati dan saling memberi tanpa harus diminta. Orang tua sebagai koordinator keluarga harus berperilaku proaktif. Jika anak menentang otoritas, segera ditertibkan karena di dalam keluarga terdapat aturan-aturan dan harapan-harapan. Anak-anak merasa aman, walaupun tidak selalu. Di antara anggota keluarga saling mendengarkan jika bicara bersama, melalui teladan dan dorongan orang tua. Setiap masalah dihadapi dan diupayakan untuk dipecahkan bersama.

Keluarga kuasa, yaitu keluarga yang lebih menekankan kekuasaan dari pada relasi. Pada keluarga ini, anak merasa seakan-akan ayah dan ibu mempunyai buku peraturan, ketetapan, ditambah daftar pekerjaan yang tidak pernah habis. Orang tua bertindak sebagai bos dan pengawas tertinggi. Anggota keluarga terutama anak-anak tidak memiliki kesempatan atau peluang agar dirinya didengarkan.

Keluarga protektif, yaitu keluarga yang lebih menekankan pada tugas dan saling menyadari perasaan satu sama lain. Dalam keluarga ini ketidak cocokan sangat dihindari karena lebih menyukai suasana kedamaian. Sikap orang tua lebih banyak pada upaya member dukungan, perhatian, dan garis-garis pedoman sebagai rujukan kegiatan. Esensi dinamika keluarga adalah komunikasi dialogis yang didasarkan pada kepekaan dan rasa hormat.

Keluarga kacau, yaitu keluarga yang kurang teratur dan selalu mendua. Dalam keluarga ini cenderung timbul konflik (masalah) dan kurang peka memenuhi kebutuhan anak-anak. Anak sering diabaikan dan diperlakukan secara kejam karena kesenjangan hubungan antara mereka dengan orang tua. Keluarga kacau selalu tidak 
rukun. Orang tua sering berperilaku kasar terhadap relasi (anak). Orang tua menggambarkan kemarahan satu sama lain dan hanya ada sedikit relasi antara orang tua dengan anak-anaknya. Anak merasa terancam dan tidak disayang. Hampir sepanjang waktu mereka dimarahi atau ditekan. Anak-anak mendapatkan kesan bahwa mereka tidak diinginkan keluarga. Dinamika keluarga dalam banyak hal serfing menimbulkan kontradiksi karena pada hakikatnya tidak ada keluarga. Rumah hanya sebagai terminal dan tempat berteduh oleh individu-individu.

Keluarga simbiotis, yaitu keluarga yang mempunyai ciri-ciri pada orientasi dan perhatian keluarga yang kuat bahkan hampir seluruhnya terpusat pada anak-anak. Keluarga ini berlebihan dalam melakaukan relasi. Orang tua sering merasa terancam karena meletakkan diri sepenuhnya pada anak-anak, dengan alasan demi keselamatan. Orang tua banyak menghabiskan waktu untuk memikirkan dan memenuhi keinginan anak-anaknya. Anak dewasa dalam keluarga ini belum memperlihatkan perkembangan sosialnya. Dalam kesehariannya, dinamika keluarga ditandai oleh rutinitas kerja. Rumah dan keluarga mendominasi para anggota keluarga (Shochib,2000:20).

Kelima tipe keluarga tersebut betul-betul terjadi pada keluarga siswa ketika dilakukan pengamatan dilingkungan sekolah dengan memperhatikan sikap dan perilaku siswa di sekolah, juga dengan melakukan pendekatan persuasif untuk mempelajari keadaan keluarganya di rumah. Juga pada lingkungan masyarakat, ketika mengamati pergaulan anak-anak di lingkungan masyarakat, apa yang dilakukan anak dalam bentuk sikap dan perilakunya betul-betul sebagai pencerminan dari kehidupan di dalam keluarganya atas pola asuh dan bimbingan serta pendidikan yang dilakukan oleh orang tuamya.

Dari hasil pengamatan dan penggalian informasi pada siswa rohis yang mereka berkepribadian baik dan rajin beribadah di lingkungan sekolahan, mereka sesuai dengan indicator yang ada pada eluarga seimbang, karena tanggung jawab dan kepercayaan orang tua yang dirasakan oleh anak menjadi dasar peniruan dan identifikasi diri untuk berperilaku. Ini berarti orang tua perlu memberikan pendidikan dan bimbingan ajaran agama Islam sebagai landasan dan arah berperilaku baik dengan rasa tanggung jawab dan konsistensi diri. Sikap saling membantu diantara anggota keluarga diperlukan untuk kesamaan arah dan tujuan dalam melakukan tindakan yang berdasarkan nilai-nilai ajaran Islam yang dianutnya. Komunikasi yang dialogis 
diperlukan untuk memahami secara jelas persoalan-persoalan. Artinya, dalam keluarga harus terjadi konfirmitas tentang nilai-nilai ajaran agama Islam yang dapat melahirkan kesadaran diri untuk berakhlak mulia dan beribadah.

\section{Peran Pendidikan Islam dalam Keluarga}

Pusat pendidikan berada pada tiga lingkungan, yaitu lingkungan keluarga, sekolah dan masyarakat. Namun diantara ketiganya, lingkungan keluarga menjadi yang paling kuat pengaruhnya terhadap perkembangan anak. Penguatan mentalitas keberagamaan berawal dari pendidikan yang dilakukan dalam lingkungan keluarga. Lingkungan keluarga menjadi institusi pendidikan pertama dalam memberikan pola asuh dan teladan dari orang tua kepada anaknya, sebagai miniatur bagi pembentukan pribadi dan perkembangan anak.

Keluarga merupakan pendidikan pertama dan utama, pertama karena keluarga merupakan lingkungan awal sebelum anak itu mengenal luar dan utama karena keluarga menjadi lingkungan sosial dan emosional dimana hal itu sangat memberikan kualitas pengalaman sehingga menjadi faktor determinan untuk pembentukan kepribadian seorang anak.

Fungsi keluarga menurut Sulaeman (1994: 84) itu ada delapan jenis, yaitu: fungsi edukasi, fungsi sosialisasi, fungsi proteksi, fungsi afeksi, fungsi religius, fungsi ekonomi, fungsi rekreasi, dan fungsi biologis. Berdasarkan kepada beberapa fungsi keluarga tersebut terlihat bahwa salah satu fungsi keluarga ialah fungsi pendidikan. Hal ini berarti bahwa orangtua sebagai pendidik pertama dan utama mempunyai kewajiban dalam memberikan pendidikan kepada anak-anaknya termasuk pendidikan nilai moral.

Proses pendidikan dalam keluarga berlangsung secara alamiah dan kultural. Interaksinya tidak berpedoman atau mengacu pada kurikulum secara baku dan sistematis, namun berjalan sesuai tuntunan dan ajaran (syariat) agama Islam, termasuk bagi pemberian pendidikan bagi anggota keluarga, dalam kacamata Islam, pendidikan menempati hal yang wajib (fardu) bagi keberlangsungan tatanan rumah tangga yang harmonis. Sehingga posisi pendidikan dalam keluarga menjadi kebutuhan mendasar (basic needs) sebagai pondasi untuk melanjutkan proses pendidikan selanjutnya di luar rumah. Ketika orang tua mengasuh dan membimbing anak-anaknya di rumah, maka pola yang dilakukan harus memperhatikan ajaran dan tuntunan agama Islam, memberikan kasih sayang, motivasi dan dukungan kepada anaknya, seorang 
anak berbakti kepada orang tuanya, saling menghormati dan toleran antar anggota keluarga, saling menghargai antara yang muda dan yang tua. Dinamisasi ini akan terwujud ketika seluruh komponen dalam keluarga saling mendukung dan melengkapi.

Pendidikan Islam di rumah (keluarga) akan berpengaruh terhadap pendidikan anak setelahnya. Rumah keluarga muslim adalah benteng utama tempat anak-anak dibesarkan melalui pendidikan Islam. Keluarga muslim adalah keluarga yang mendasarkan aktivitasnya pada pembentukan keluarga yang sesuai dengan syariat Islam. Tanggungjawab orang tua menjadi semakin penting mengingat banyaknya sendi kehidupan sosial yang melenceng dari tujuan pendidikan, khususnya tujuan pendidikan Islam, baik itu berupa pengaruh dari internet, media massa, tayangan radio dan televisi atau tempat-tempat yang dilegalisasi untuk pelecehan seksual. Keluarga, terutama orang tua bertanggungjawab untuk memberikan kasih sayang kepada anakanaknya, karena kasih sayang merupakan landasan terpenting dalam pertumbuhan dan perkembangan psikologis dan sosial anak (An Nahlawi,1995:141)

Dari hasil penggalian informasi terhadap siswa rohis tentang perhatian orang tuanya dalam pendidikan Islam dilakukan dengan pola pembinaan sebagai berikut:

1. Memberikan teladan yang baik kepada mereka dan membimbingnya untuk berpegang teguh kepada ajaran-ajaran agama dalam bentuknya yang sempurna dalam waktu tertentu.

2. Memberi contoh yang baik bagi anak-anak dalam berpegang teguh kepada ajaranajaran agama dan akhlak yang mulia.

3. Membiasakan mereka melaksanakan syiar-syiar agama semenjak kecil sehingga pelaksanaan itu menjadi kebiasaan yang mendarah daging, sehingga mereka melakukannya dengan kemauan sendiri serta merasa tenteram dalam melaksanakannya.

4. Menyiapkan suasana agama dan spiritual yang sesuai di rumah dimana mereka berada.

5. Membimbing mereka membaca bacaan-bacaan agama yang berguna dan memikirkan ciptaan-ciptaan Allah dan makhluk-makhluk-Nya untuk menjadi bukti kehalusan sistem ciptaan itu dan atas wujud dan keagungan-Nya. (Getteng,1997:62) 
Dengan memperhatikan tujuan dari pendidikan agama Islam di dalam keluarga tersebut menunjukkan adanya garis sejajar antara tingkat keharmonisan keluarga dengan tingkat amaliah ajaran agama Islam dalam keluarga. Dengan demikian kunci dari kekokohan dan keharmonisan keluarga serta kepribadian yang baik yang dimilikinya menunjukkan kuatnya amaliah agama yang dianutnya.

\section{Peran Keluarga bagi Anak-anak}

Orang tua dalam keluarga adalah sebagai pendidik bagi anak-anaknya. Karena keluarga merupakan unit pertama dan institusi pertama dalam masyarakat di mana hubungan-hubungan yang terdapat di dalamnya, sebahagian besarnya bersifat hubungan langsung dan di situlah berkembang individu dan di situ pulalah terbentuknya tahap-tahap awal proses sosialisasi bagi anak-anak. Dari interaksi dalam keluarga inilah anak-anak memperoleh pengetahuan, keterampilan, minat, nilai-nilai, emosi dan sikapnya dalam hidup dan dengan itu pulalah mereka memperoleh ketenteraman dan ketenangan.

Bimbingan dan pendidikan yang diberikan oleh orang tua kepada anak-anaknya merupakan langkah pembentukan kepribadian anak. Kepribadian anak yang baik merupakan faktor dominan juga terbentuknya keluarga yang harmonis. Perlakuan orang tua yang penuh kasih sayang dan pendidikan nilai-nilai kehidupan, baik nilai agama maupun nilai sosial budaya yang diberikan kepada anak merupakan faktor yang kondusif untuk mempersiapkan anak menjadi pribadi dan warga masyarakat yang sehat dan produktif.

Dalam perkembangan kepribadian anak sangat dipengaruhi suasana keluarga. Seorang anak yang dibesarkan dalam lingkungan keluarga yang harmonis dan agamis, yaitu suasana yang memberikan curahan kasih sayang, perhatian, dan bimbingan dalam bidang agama, maka perkembangan kepribadian anak tersebut cenderung positif, sehat. Sedangkan anak yang dikembangkan dalam lingkungan keluarga yang berantakan, tidak harmonis, keras terhadap anak dan tidak memperhatikan nilai-nilai agama, maka perkembangan kepribadiannya cenderung mengalami distorsi atau mengalami kelainan dalam penyesuaian dirinya.

Dalam Islam, keluarga mempunyai kewajiban mendidik anak-anaknya dengan tujuan agar dapat merealisasikan ajaran Islam dan rukun iman di dalam jiwa dan tingkah laku mereka. Termasuk yang lebih penting mendidik kepribadian anak, karena setiap anak dilahirkan dalam keadaan suci batin dan sehat fitrahnya (An 
Nahlawi,1983:201). Dalam lingkungan keluarga, orang tua menentukan pola pembinaan pertama bagi anak. Pendidikan anak mutlak dilakukan oleh orang tuanya untuk menciptakan keseluruhan pribadi anak yang maksimal. Melalui pendidikan terhadap anak, khususnya orang tua akan terhindar dari bahaya fitnah dan terhindar pula dari bahaya siksa api neraka sebagaimana dijelaskan dalam al-Qur'an Surat atTahrim ayat 6 (Saebani,2010:113).

Dari hasil penggalian informasi terhadap siswa yang mengikuti rohis dan memiliki kepribadian yang baik dibandingkan dengan siswa yang lain, ternyata pola asuh yang diberikan orang tua terhadap anaknya dalam keluarga sesuai teori yang ada, yaitu dengan langkah-langkah sebagai berikut :

1. Mengingatkan untuk selalu untuk melaksanakan kewajiban beribadah untuk menumbuhkan kesadaran beribadah.

2. Memberi contoh yang baik bagi anak-anaknya dalam berpegang teguh kepada akhlak mulia.

3. Menyediakan bagi anak-anaknya peluang-peluang dan suasana praktis di mana mereka dapat mempraktekkan akhlak yang diterima dari orang tuanya.

4. Memberi tanggung jawab yang sesuai kepada anak-anaknya supaya mereka bebas memilih dalam tindak-tanduknya.

5. Menunjukkan bahwa keluarga selalu mengawasi mereka dengan sadar dan bijaksana.

6. Menjaga mereka dari teman-teman yang menyeleweng dan tempat-tempat kerusakan, dan lain-lain lagi cara di mana keluarga dapat mendidik akhlak anakanaknya.

\section{SIMPULAN}

Keluarga merupakan tempat pertama perkenalan anak sebelum ia berkenalan dengan dunia sekitarnya. Pengalaman pergaulan dalam keluarga memberikan pengaruh yang sangat besar bagi perkembangan anak untuk masa yang akan datang. Keluargalah yang memberikan warna kehidupan seorang anak, baik perilaku, budi pekerti, amaliah beragama maupun adat kebiasaan sehari-hari. Keluarga jugalah tempat seorang anak mendapat tempaan pertama kali yang kemudian menentukan baik buruk kehidupan setelahnya di masyarakat. 
Penerapan pendidikan agama terhadap anak dalam keluarga sangat berpengaruh terhadap pembentukan sikap dan tingkah laku anak. Pemberian modal-modal keagamaan dalam keluarga, secara garis besarnya dapat melahirkan implikasiimplikasi sebagai berikut: 1) anak memiliki pengetahuan dasar-dasar keagamaan, 2) anak memiliki pengetahuan dasar akhlak, 3) anak memiliki pengetahuan dasar sosial. Pengetahuan-pengetahuan dasar tersebut memiliki arti penting untuk pencapaian tujuan asasi dari pendidikan Islam, yaitu penanaman iman dan akhlakul karimah.

\section{DAFTAR PUSTAKA}

Achidsti, S. (2014). "Eksistesinsi Kyai dalam Masyarakat”. IBDA': Jurnal Kebudayaan Islam, 12 (2), 149-171.

Fachrudin. (2011). "Peranan Pendidikan Agama dalam Keluarga terhadap Pembentukan Kepribadian Anak-anak". Ta'lim-Jurnal Pendidikan Islam. Vol.9(1)

Getteng, H. Abd. Rahman. (1997). Pendidikan Islam dalam Pembangunan. Ujungpandang: Yayasan al-Ahkam.

Haris, Munawir. (2019). “Urgensi Pendidikan Agama dalam Keluarga dan Implikasinya

Terhadap Pembentukan Kepribadian Anak" . MASILE. Vol.1 (1):Juli-Desember.

Hasyim, Umar. (1985). Cara Mendidik Anak dalam Islam, Seri II. Surabaya: Bina Ilmu.

Jalaluddin. (2010). Psikologi Agama. Jakarta: Rajawali Pers.

Mahmud, (2013), Pendidikan Agama Islam dalam Keluarga, Bandung: Akademia Permata.

Muflihin, A. (2016). Paradigma Keilmuan Integrasi-Interkoneksi: Studi Terhadap Desain dan Implementasi Kurikulum Program Magister Prodi Pendidikan Islam Fakultas Ilmu Tarbiyah dan Keguruan UIN Sunan Kalijaga Yogyakarta. Thesis Post-Graduate, UIN Sunan Kalijaga.

Muhaimin dan Abd. Mujib. (1993). Pemikiran Pendidikan Islam; Kajian Filosofis Kerangka Dasar Operasionalnya. Cet. I; Bandung: Trigenda Karya.

Mushthafa, Ibnu. (1997). Keluarga Islam Menyongsong Abad 21. Cet. II; Bandung: Mizan.

Rivai, Melly Sri Sulastri. (1993). Suatu Tinjauan Historis Prospektif tentang Perkembangan Kehidupan dan Pendidikan Keluarga, dalam Jalaluddin Rahmat dan Myhtar Gandaatmaja (peny.), Keluarga Muslim dalam Masyarakat Modern. Cet. I; Bandung: Remadja Rosda karya. 
64 | Ahmad Masduki

Shochib, Moh. (2000). Pola Asuh Orang Tua. Jakarta: Rineka Cipta.

Soelaeman. (1978). Pendidikan dalam Keluarga. Diktat Kuliah. UPI Bandung

Suharnis. (2015). "Nilai-nilai Pendidikan Islam dalam Keluarga”. MUSAWA, Vol. 7 (1): $52-79$.

Ulwan, Abdullah Nasih . (2007), Pendidikan Anak dalam Islam, Jakarta: Pustaka Imani.

Zed, Mestika. (2008). Metodelogi Penelitian Kepustakaan. Jakarta: Yayasan Obor Indonesia. 